\title{
Partial Replacement of Coarse Aggregate by using Recycled Aggregate
}

\author{
K. Sathish Kumar, S. Rajesh, Vinoth Kumar.S
}

\begin{abstract}
The high and rapidly rising cost of cement has made construction expensive in developing countries where cement is commonly used. Tests were conducted in this undertaking research with the selection of necessary materials and information required for the configuration of the blend is collected. Cubes and cylinders were casted with these concrete mixtures and subjected to 7-day, 14-day and 28-day healing and determining their strength. The determined compressive strength and spilt tensile strength was compared with the conventional concrete for percentage replacements of $(0 \%, 5 \%, 10 \%, 15 \%)$.
\end{abstract}

Keywords: compressive strength, extravagant, blend configuration

\section{INTRODUCTION}

\section{A. General}

Preservation of asset is consistently the need of mankind. In the beginning of time/development, we have utilized the assets yet not long after we have begun once again misuse. This outcomes in the shortage of assets. Later on we have known the way that we have to moderate the assets. In this manner human have concluded that we need to utilize assets productively. Reused total can be utilized for some reasons. They can be utilized in buildings and dams[1]-[6]

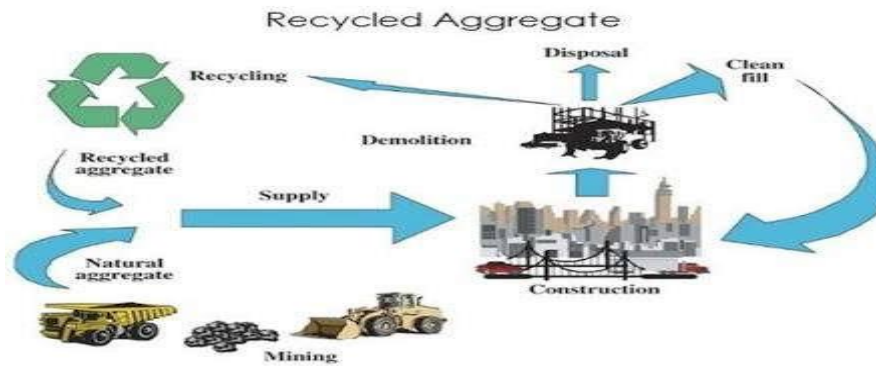

\section{OBJECTIVES}

1. To study the workability of concrete .

2. To study the compressive and split tensile (strength) with various Percentage replacement of recycled coarse aggregate $(5 \%, 10 \% \& 15 \%)$

Revised Manuscript Received on October 22, 2019.

K. Sathish Kumar, Assistant Professor, Department Of Civil Engineering,,Bharath Institution of Higher Education And Research,TamilNadu, India Emailsathish_4549@yahoo.co.in

S. Rajesh, Assistant Professor,,Department Of Civil Engineering,,Bharath Institution Of Higher Education And Research,TamilNadu, India .Email: rajeshskr06@gmail.com

Vinoth Kumar.S, Asistant Professor, Department Of Civil Engineering,,Bharath Institution of Higher Education And Research,TamilNadu, India Email: vinothsenna@gmail.com
3. To reduce the impact of waste material on construction.

\section{MATERIAL TESTING}

A. FINE AGGREGATE:

TEST FOR SPECIFIC GRAVITY:

Fine Aggregate total utilized in this investigation is locally accessible and affirmed to reviewing zone II according to IS383-1970, the total whose size is under $4.75 \mathrm{~mm}$. Sand is commonly considered to have a lower size utmost of about $0.07 \mathrm{~mm}$.

\section{Table:Physical Parameters of Fine aggregate}

\begin{tabular}{|l|l|l|}
\hline Si. No & Parameters & Results \\
\hline 1 & Specific Gravity & 2.19 \\
\hline
\end{tabular}

\section{COARSE AGGREGATE:}

Coarse total will comprise of squashed or broken stones and be hard, solid, tense, sturdy, spotless and legitimate degree. The properties of coarse aggregate studied where impact value, Los Angel's abrasion test and specific gravity test.

\section{CEMENT:}

Concrete sets or fixes when blended with water which causes a progression of hydration substance responses.

The properties of cement initial setting time and specific gravity is studied.[6]-[13]

\section{Table: Physical Parameters of cement}

\begin{tabular}{|l|l|l|}
\hline Si. No & Parameters & Results \\
\hline 1 & Specific Gravity & 3.15 \\
\hline 2 & Initial setting time & 42 minutes \\
\hline 3 & Fineness & $95 \%$ \\
\hline
\end{tabular}

Water is to be utilized in the solid work ought to have the accompanying properties: It ought to be free from antagonistic measure of soil, soluble bases or other natural or inorganic impurities.It ought to be free from iron, vegetable issue or some other sort of substances, which are probably going to have unfriendly impact on cement or support. 


\section{RECYCLED COARSE AGGREGATE:}

Reused Aggregate comprises of hard, graduated parts of dormant mineral materials.

Table: Physical Parameters of Recycled Coarse aggregate

\begin{tabular}{|l|l|l|}
\hline Si.No & Parameters & Results \\
\hline 1 & Specific Gravity & 2.74 \\
\hline
\end{tabular}

Table: Physical Parameters of coarse aggregate

\begin{tabular}{|l|l|l|}
\hline Si. No & Parameters & Results \\
\hline 1 & Specific Gravity & 2.73 \\
\hline 2 & Impact Factor & $19.51 \%$ \\
\hline 3 & Water Absorption & $4 \%$ \\
\hline
\end{tabular}

TEST FOR CONCRETE

\section{SLUMP TEST:}

Slump test is the most consistently used method for assessing consistency of strong which can be used either in research focus or at site of work

\begin{tabular}{|l|l|l|}
\hline Si. No & \%Replacement & Slumpralue (mm) \\
\hline 1 & $0 \%$ & 70 \\
\hline 2 & $5 \%$ & 90 \\
\hline 3 & $10 \%$ & 110 \\
\hline 4 & $15 \%$ & 140 \\
\hline
\end{tabular}

\section{COMPACTION FACTOR TEST:}

Compacting component of fresh bond is done to choose the handiness of the new concrete by compacting segment test. The compacting factor mechanical assembly is utilized to decide the compaction factor of cement with low, medium and high use fulness.

Table : Compaction Factor

\begin{tabular}{|l|l|l|}
\hline Sl. no & \% Replacement & Compaction factor \\
\hline 1 & $0 \%$ & 0.847 \\
\hline 2 & $5 \%$ & 0.884 \\
\hline 3 & $10 \%$ & 0.982 \\
\hline 4 & $15 \%$ & 0.991 \\
\hline
\end{tabular}

\section{RESULTS AND DISCUSSIONS}

The results of compressive and tensile test with partial replacement of recycled coarse aggregate is tabulated.

\section{COMPRESSIVE STRENGTH TEST:}

The compressive test of concrete is tested for $0 \%, 5 \%, 10 \% \&$ $15 \%$. The table below shows compressive strength of concrete.

\begin{tabular}{|l|l|l|l|l|}
\hline $\begin{array}{l}\text { Si. } \\
\text { No }\end{array}$ & $\begin{array}{c}\text { Replacement } \\
7\end{array}$ & $\begin{array}{c}\text { cubes }\left(\mathrm{Nmm}^{2}\right) \\
7 \text { days }\end{array}$ & $\begin{array}{c}\text { Cubes }\left(\mathrm{Nmm}^{2}\right) \\
14 \text { days }\end{array}$ & $\begin{array}{c}\text { Cubes }\left(\mathrm{Nmm}^{2}\right) \\
28 \text { days }\end{array}$ \\
\hline 1 & $0 \%$ & 16.55 & 22.42 & 29.67 \\
\hline 2 & $5 \%$ & 18.30 & 24.85 & 31.42 \\
\hline 3 & $10 \%$ & 13.06 & 20.71 & 26.56 \\
\hline 4 & $15 \%$ & 10.90 & 15.62 & 20.12 \\
\hline
\end{tabular}

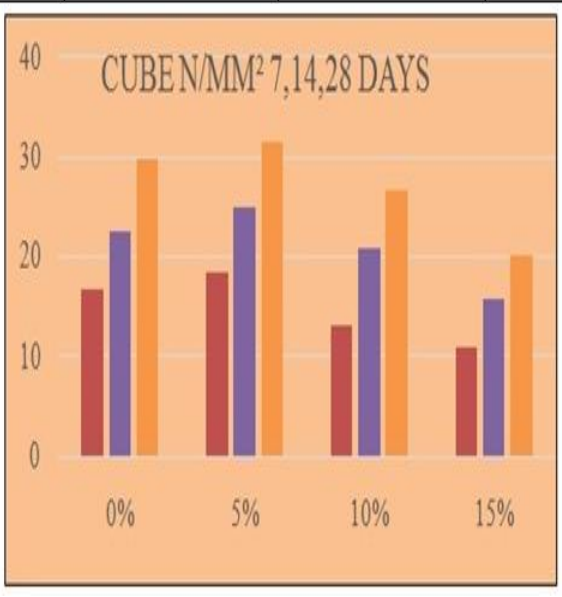

Fig1 : compressive strength of cube

\section{SPLIT TENSILE STRENGTH:}

The tensile test of concrete is tested for $0 \%, 5 \%, 10 \% \& 15 \%$. The table below shows tensile strength of concrete.

Table: Split Tensile Strength Of Cylinders

\begin{tabular}{|c|c|c|c|c|}
\hline $\begin{array}{l}\mathrm{Si} \\
\mathrm{No}\end{array}$ & $\begin{array}{c}\% \\
\text { Replacement } \\
\end{array}$ & $\begin{array}{c}\text { Cylinders (N/mm²) } \\
7 \text { days } \\
\end{array}$ & $\begin{array}{c}\text { Cylinders ( }\left(\mathrm{Nmm}^{2}\right) \\
14 \text { days }\end{array}$ & $\begin{array}{c}\text { Cylinders ( }\left(\mathrm{Nmm}^{2}\right) \\
28 \text { days } \\
\end{array}$ \\
\hline 1 & $0 \%$ & 1.03 & 1.87 & 2.70 \\
\hline 2 & $5 \%$ & 2.49 & 3.32 & 4.15 \\
\hline 3 & $10 \%$ & 2.07 & 2.91 & 3.74 \\
\hline 4 & $15 \%$ & 1.03 & 1.87 & 2.70 \\
\hline
\end{tabular}

TABLE 6: split tensile strength of cylinder

\section{CONCLUSION}

In this experimental study, the cubes \& cylinder were casted with the various percentages of recycled aggregates $(0 \%, 5 \%$, $10 \%$, and $15 \%$ ) in the concrete.

1. Workability of concrete increases when various percentages of recycled aggregates.

2. Specimen casted with $\mathrm{OPC}+$ recycled aggregate $(5 \%)$ shows the maximum compressive strength. 
3. Specimen casted with OPC + recycled aggregate $(5 \%)$ shows the maximum tensile strength.

\section{REFERENCES}

1. $\quad$ Sathish Kumar, K., Vinothkumar, S., Venkatakrishnaiah, R. \& Mohan, S.J. 2019, "Experimental investigation on rehabilitation of corroded concrete beam specimens", International Journal of Civil Engineering and Technology, vol. 10, no. 1, pp. 2949-2955.

2. Kanchanabhan, T.E., Krishnaiah, R.V., Dayakar, P. and Mani, A., 2019. A detailed study on green building concept in construction industry. International Journal of Civil Engineering and Technology, 10(1), pp. 2944-2948.

3. Mugilvani, P., Murugan, S.T., Kaviya, B. and Sathishkumar, K., 2019. Experimental investigation on nano concrete. International Journal of Civil Engineering and Technology, 10(1), pp. 907-912.

4. Vinothkumar, S., Sathishkumar, K., Anish, C. and Rajesh, S., 2019. Characteristic strength of concrete by partial replacement with sawdust and waste ceramic tiles. International Journal of Civil Engineering and Technology, 10(1), pp. 2821-2829.

5. Chitra, R., Thendral, S., Arunya, A. and Mohan, S.J., 2019. Experimental study on strength of concrete by partial replacement of fine aggregate with saw dust. International Journal of Civil Engineering and Technology, 10(1), pp. 2766-2769.

6. Mani, A., Meikandaan, T.P., Gowrishankar, P.G. and Kanchanabhan, T.E., 2019. A study on treatment of industrial effluent (dyeing) using moringa oleifera, tamarina indica as coagulants. International Journal of Civil Engineering and Technology, 10(1), pp. 2796-2811.

7. Frank Stephen, S., Chockalingam, M.P., Nalanth, N. and Lekshmy Raghavan, P., 2019. Study on the fresh state properties of self compacting concrete modified with recycled concrete aggregate. International Journal of Civil Engineering and Technology, 10(1), pp. 1205-1212.

8. Dayakar, P., Raman, K.V., Arunya, A. and Venkatakrishnaiah, R., 2019. Study on strength properties of sand by biocementation with eggshell. International Journal of Civil Engineering and Technology, 10(1), pp. 2770-2785.

9. Shendge, R.B., Chockalingam, M.P., Saritha, B. and Ambica, A., 2018. Swat modelling for sediment yield: A case study of Ujjani reservoir in Maharashtra, India. International Journal of Civil Engineering and Technology, 9(1), pp. 245-252.

10. Meikandaan, T.P. and Hemapriya, M., 2017. Use of glass FRP sheets as external flexural reinforcement in RCC Beam. International Journal of Civil Engineering and Technology, 8(8), pp. 1485-1501.

11. Harini, A.T., 2017. Experimental study on utilisation of ceramic wastes in concrete. International Journal of Civil Engineering and Technology, 8(8), pp. 1346-1352.

12. Ambica, A., Sartiha, B. and Anbarasan, R., 2017. Groundwater quality assessment using water quality index and GIS, Maduravoyal, Chennai, India. International Journal of Civil Engineering and Technology, 8(8), pp. 1375-1381.

13. Aswathy, M., Saritha, B. and Chockalingam, M.P., 2019. Degradation of anionic dye using $\mathrm{Fe} / \mathrm{Tio} 2$ composite by photocatalysis. International Journal of Innovative Technology and Exploring Engineering, 8(9 Special Issue 3), pp. 788-791

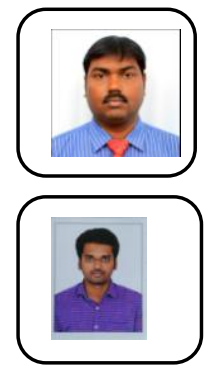

S.Rajesh, Asistant Professor, Department Of Civil Engineering,,Bharath Institution of Higher Education And Research,TamilNadu, India

Vinoth Kumar.S Assistant Professor,,Department Of Civil Engineering,,Bharath Institution Of Higher Education And Research,TamilNadu, India

\section{AUTHORS PROFILE}

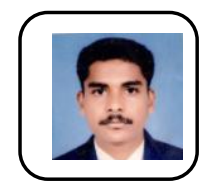

K.Sathish Kumar Asistant Professor, Department Of Civil Engineering,,Bharath Institution of Higher Education And Research,TamilNadu, India 